\title{
Central Bank Intervention in the Inflation Targeting
}

\begin{abstract}
This paper analyses the impact of central bank interventions in the inflation targeting regime. The results of empirical studies in this paper show if there is a shock of the exchange rate, which would lead to depreciation of the exchange rate, a central bank may decide to mush instability on the foreign exchange market with foreign exchange interventions, thereby preventing the sudden exchange rate depreciation, which would then require a smaller reaction by the interest rate. Namely, through foreign exchange interventions, the central bank greatly absorbs the depreciation shock and, consequently, inflation is lower. As a result of lower price growth, the need for a monetary policy response to an interest rate is also lower. Based on this example, we can see that central bank intervention in some cases can be very useful in order to correct disturbances in the foreign exchange market. Therefore, some central banks accumulate foreign exchange reserves at a very high level so as to have enough space for foreign exchange intervention, without the risk of falling foreign exchange reserves below the optimum level.
\end{abstract}

Keywords: central bank intervention, inflation targeting, foreign exchange reserves, exchange rate.

JEL Classification: E52, E58, F31, C50, G15.

\section{Introduction}

Central bank intervention in the foreign exchange market involves the purchase or sale of domestic currency in exchange for foreign currency aiming to influence the exchange rate. Interventions are used to ensure liquidity in the foreign exchange market or the impact on the exchange rate and foreign exchange reserves. 
Over the past several decades, financial markets and institutions in developed countries underwent radical transformation and a sudden expansion, induced by general trends in deregulation, liberalisation, globalisation, as well as computer technologies advances (Fabris, 2019). The frequency of intervention in developed countries has declined since the foreign exchange market in these countries is deep enough to absorb the major shocks. However, due to the lack of deep foreign exchange markets in developing and emerging countries, floating exchange rate regime may cause the collapse of the foreign exchange market and currency crisis.

For a small and open economy, the movement of the exchange rate has a significant impact on the economy, particularly on inflation and GDP. In addition, there may come to the breaking of the exchange rate. In this case, the central bank intervention may limit the degree of overshooting of the exchange rate, thus avoiding the negative impact and the need for expensive real macroeconomic adjustment. In a flexible exchange rate regime, there is no target exchange rate. Interventions are aimed at correcting and preventing excessive and persistent volatility of the exchange rate but not to oppose exchange rate variations that are in line with fundamentals. If the pressure on the exchange rate reflects the fundamental economic forces, then no intervention is needed but it is necessary to adjust the exchange rate. Exchange rate volatility may complicate the achievement of inflation targets.

The primary objective of a central bank is to act preventively to preclude the appearance of a crisis (Fabris, 2018). The role of central bank interventions depends on the monetary strategy. In exchange rate targeting (fixed exchange rate) regime, the central bank intervenes to achieve and maintain target exchange rate. In this regime, a direct connection (via interest rates) is established between the balance of payments and money supply. In other words, changing the balance (imbalance) of the balance of payments is equal to the change in foreign exchange reserves. The exchange rate is constant, and foreign exchange reserves are changing. The link between the balance of payments and money supply may be a partially interrupted sterilization (depending on the level of foreign exchange reserves and capital mobility). In the case of balance of payments deficit, the central bank needs to sell foreign exchange reserves and purchases domestic government bonds. In the case of a surplus, it should buy foreign exchange reserves and sell domestic government bonds. On the other hand, in inflation targeting (flexible exchange rate), if the cycle of exchange rate jeopardizes the achievement of the inflation target, the central bank should intervene in the foreign exchange market. In a flexible exchange rate regime, a direct connection (via the exchange rate) is established between the balance of payments and money supply. In other 
words, changing the balance (imbalance) balance of payments is equal to the change in the exchange rate. Foreign exchange reserves are held constant, and the exchange rate changes. Therefore, inflation targeting does not exclude central bank intervention in the foreign exchange market. However, these central bank interventions are not aimed at achieving and maintaining the exchange rate target but rather on achieving and maintaining a defined inflation target that would be endangered by the exchange rate cycle.

There is a difference between interventions that change (non-sterile interventions) and interventions that do not change the monetary basis (sterilized interventions). Sterilization is a central bank operation that neutralizes the impact of foreign exchange intervention on money supply. It implies the purchase or sale of securities that correspond to the amount of intervention in the foreign exchange market, but are the opposite sign. Sterilization is estimated in the short term as a difference between net foreign assets and net domestic assets as it aims to maintain a constant money supply. Sterilization is usually the first reaction of monetary policy to a sudden increase in capital inflows. The net effect of sterilization is an unchanged monetary base, but the share of foreign exchange reserves in the fund of central bank assets is increasing. The purpose of sterilization is to prevent excessive appreciation of the real exchange rate. In the fixed exchange rate regime, a re-absorption of the domestic currency that is released into circulation is required to purchase an increased capital inflow (government central bank bonds) or an increase in the reserve requirement rate (limitation of bank loans). In the flexible exchange rate regime, the central principle of the central bank is not to intervene in the foreign exchange market at all. A sharp appreciation of the exchange rate would result in an increase in capital inflows. If the central bank wants to prevent the appreciation of the exchange rate, then it buys foreign currency on the foreign exchange market. In order to do this in a non-inflationary manner, it issues government bonds to limit bank loans.

Central bank interventions have a slight influence on the real exchange rate if the foreign reserves accumulation increases the monetary base and inflation for the amount of nominal appreciation of the exchange rate. The real exchange rate is constant when the nominal exchange rate changes in proportion to the inflationary differential. Via the neutralizing effect of foreign exchange intervention on a monetary basis, sterilization allows the central bank to affect the real exchange rate. However, over time it is increasingly difficult to sterilize. The problem is that sterilization only prolongs the imbalance of the balance of payments because it is an automatic adjustment mechanism that provides foreign exchange reserves flows in the monetary approach to the balance of payments. Another potential problem is a quasi-fiscal deficit. If a central bank has to pay a high interest rate to 
encourage the private sector to absorb "sterilization bonds" whilst achieving a low interest rate on foreign securities, it then records a deficit.

The basic hypothesis to be tested in this paper is the analysis of the efficiency of central bank interventions on the foreign exchange market in inflation targeting. The rest of this paper is organized as follows. Section 2 considers a preliminary examination of literature from the relevant scientific field. The hypotheses of interest are given in Section 3 that also describes the econometric model to be used in the analysis of central bank intervention in inflation targeting and considers the data, methodologies and variables used in the study. A discussion of the results and implications is given in Section 4. Section 5 provides concluding observations and recommendations for future research based on empirical research in this paper.

\section{Literature Review}

Katusiime \& Agbola (2018) show that foreign exchange interventions a mixed impact on the volatility of the exchange rate and find that inflation targeting is capable of curbing temporary exchange rate shocks. Empirical results indicate that while order flow is capable of reducing exchange rate volatility, an increase in the operating target rate tends to exacerbate exchange rate volatility. They argued that inflation targeting is an effective monetary policy tool for curbing exchange rate volatility. Mundaca (2018) found that interventions in the foreign exchange market by the Banco Central de Reserva del Peru have been effective in moving the sol/USD in the intended direction during both the past managed floating regime and the current inflation targeting regime. However, interventions have increased the volatility of the sol/USD and this has continued very strongly under the inflation targeting regime. A conclusion is that the Banco Central de Reserva del Peru might not yet have gained a sufficiently strong reputation to effectively reduce the exchange-rate volatility. Dutt (2018) seeks to estimate the costs of foreign exchange intervention undertaken by central banks around the world, and examines how these costs are affected by country characteristics and also the variation of the costs between advanced and developing countries, including the effect of policy tools on these costs. Abbuy (2018) investigated the effectiveness of foreign exchange intervention of central banks of Canada and Switzerland and showed that interventions generally reduce exchange rates volatility. However, the Swiss National Bank seemed to be more efficient in stabilizing its currency than the Bank of Canada whose interventions, despite being effective, have failed to stabilize the country's currency. Guler (2020) found that announcement of 
an inflation target that is not supported by credibility would not be enough to anchor inflation expectations.

Chang (2017) showed that central bank sterilization may (or may not) have real effects because it changes the net credit position of the central bank vis-à-vis financial intermediaries, thereby affecting external debt limits. A sterilized sale of foreign exchange reserves relaxes the constraints by reducing the central banks debt to domestic banks, freeing resources to increase the supply of credit to domestic agents. Fratzscher, Gloede, Menkhoff, Sarno and Stöhr, (2017) examined central bank intervention based on daily data covering 33 countries from 1995 to 2011 and found that central bank intervention is widely used as an effective policy tool with a success rate over 80 percent under some criteria. The policy works well in terms of smoothing the path of exchange rates, and in stabilizing the exchange rate in countries with narrow band regimes. Cavallino (2017) studied capital flows shocks that cause inefficient exchange rate fluctuations that trigger boom-bust cycles in the domestic economy and showed that the optimal policy response on capital flows shocks is to partially stabilize these fluctuations using both foreign exchange intervention and monetary policy. The optimal foreign exchange intervention leans against the wind and stabilizes the path of the exchange rate: following an increase (decrease) in the foreign demand for domestic assets, the central bank increases (decreases) their net supply and accumulates (decumulates) foreign reserves. By doing so, the central bank stabilizes the path of the exchange rate and smooths out fluctuations in domestic consumption. Simultaneously, the central bank reduces (increases) the nominal interest rate in order to reduce the relative price of domestic goods and mitigate the output gap. Foreign exchange intervention is not a mere substitute for monetary policy but these are just two tools that complement each other. Fanelli and Straub (2017) developed a theory of foreign exchange interventions in a small and open economy with limited capital mobility. Home and foreign bond markets are segmented and intermediaries are limited in their capacity to arbitrage across markets. As a result, the central bank can implement nonzero spreads by managing its portfolio. Crucially, spreads are inherently costly, over and above the standard costs from distorting households' consumption profiles. Optimal central bank interventions balance these costs with terms of trade benefits. They showed that central bank intervention leans against the wind of global capital flows to avoid excessive currency appreciation.

Montoro and Ortiz (2016) analysed the effectiveness of different strategies of central bank intervention (e.g. unanticipated operations or via a preannounced rule) to affect volatility of the exchange rate and the transmission mechanism of the interest rate and found that: central bank intervention has a strong interaction 
with monetary policy in general equilibrium; central bank intervention rules can have stronger stabilisation power than discretion in response to shocks because they exploit the expectations channel and there are some trade-offs in the use of central bank intervention since it can help isolate the economy from external financial shocks, but it prevents some necessary adjustments to the exchange rate as a response to nominal and real external shocks. Cun and Li (2016) showed that both M2 and bank credit had significantly increased during the sterilized intervention period, regardless of monetary base being kept unaffected, implying an increase in money multiplier. As banks' holdings of central bank bills increase, they hold less excess reserves, leading to a higher money multiplier and expansions of banks' balance sheets. Comparing to open market operation, raising required reserve ratio, which directly freezes the increase in monetary base caused by intervention, can be more effective for stabilizing the economy. When the central bank is allowed to use reserve requirement as an additional policy instrument, the fluctuations in macroeconomic variables are significantly reduced. Trivedi and Srinivasan (2016) find that direct central bank intervention through sale or purchase of foreign currency is not successful in influencing the direction of exchange rate movement and does not have any statistically significant impact on volatility as corroborated by both monthly and daily data. Blanchard, Adler and de Carvalho Filho (2015) found that larger foreign exchange intervention leads to less exchange rate appreciation in response to gross inflows. Fatum (2015) showed that when interest rates are zero intervention works through the portfolio-balance channel.

Williams (2014) found critical issues for inflation targeting going forward: the constraint of the zero lower bound on nominal interest rates and the appropriate role of monetary policy in supporting financial stability. This has led to the development of alternative approaches to inflation targeting that offer, in theory, potential advantages with respect to the zero lower bound and financial stability. Choi \& Jin (2014) investigated whether China can benefit from a trade surplus in one period, using it to pay off the debt in the next period by manipulating the exchange rates. If the marginal utility of income is non-increasing in the exchange rate, then the equilibrium exchange rates that yield a trade balance in each period maximize the total utility over two periods, regardless of the interest rate. Daude, Levy Yeyati \& Nagengast (2014) found that, on average, intervention is effective in moving the real exchange rate in the desired direction, controlling for deviations from the equilibrium and short-term changes in fundamentals and global financial variables. They found little evidence of asymmetries in the effect of sales and purchases, but some evidence of more effective interventions for large deviations from the equilibrium. Atish, Ostry and Chamon (2014) showed that in the presence of domestic or foreign shocks, discretionary policies or inflation target- 
ing may be preferable, depending on the severity of time inconsistency problems. The use of central bank intervention as a second instrument improves welfare under both regimes, but more so under inflation targeting. Adler and Tovar (2014) suggested that interventions slow the pace of appreciation, but the effects decrease rapidly with the degree of capital account openness. At the same time, interventions are more effective in the context of already overvalued exchange rates. Fatum and Yamamoto (2014) found no evidence that small central bank interventions exert a discernible influence on the exchange rate while large central bank interventions significantly influence the exchange rate in the theoretically consistent manner. They concluded that small central bank interventions may not be considered a determinant of the exchange rate while large central bank interventions constitute an important element in our understanding, and modelling, of the exchange rate.

Canzoneri and Cumby (2013) showed that discretion may be the better part of valour: pure inflation targeting may come closer to the optimal policy than exchange rate smoothing. A secondary result may also be of some interest: foreign exchange interventions have a stronger impact on inflation and output in an inflation targeting regime than do sterilized interventions; the Taylor rule augments the effects of a given intervention. Fernandes (2013) found that the behaviour of some variables (risk premium, the deviations of the real from its prior trend, comparison of the performance of the real with that of similar currencies, the volatility of markets and of the exchange rate) strongly influence the likelihood of central bank intervention. He also concluded that the central bank intervention a day earlier increases the likelihood of a new intervention. Cheng, Das and Shimatani (2013) found that the central bank interventions in Japan had increased market volatility which not only caused short-lived positive jumps but were also persistent over time. They did not find any evidence that interventions were effective in influencing the exchange rate returns for the entire sample period. FryMcKibbin \& Wanaguru (2013) found that in the low volatility period in the first part of the sample, the central bank is successful in influencing the exchange rate when pressure is to appreciate, accumulating foreign exchange reserves. The same model estimated for the global volatility period in the second part of the sample shows the central bank intervenes to mitigate excessive exchange rate volatility in line with the short-term objective. The results point to the need to consider the cross-currency market interdependence between emerging markets when modelling intervention. Fatum, Pedersen \& Sorensen (2013) showed that central bank intervention purchases and sales both exert a significant influence on the exchange rate spread, but in opposite directions: intervention purchases of the smaller currency, on average, reduce the spread while intervention sales, on average, increase the spread. They also showed that central bank intervention 
only affects the exchange rate spread when the state of the market is not abnormally volatile. Their results are consistent with the notion that illiquidity arises when traders fear speculative pressure against the smaller currency. Jin \& Choi (2013) showed possible gains from central bank intervention using a two-period framework in which a trade surplus in one period must be offset by a trade deficit in the next period. It is shown that when the interest rate is zero, the optimal policy is non-intervention. If the interest rate is positive, a country may earn positive profits by incurring a trade surplus in the first period. However, there is an upper bound for optimal trade surplus. A country actually may lose money if the rate of devaluation below the equilibrium is greater than the interest rate. Basu \& Varoudakis (2013) showed that when the foreign exchange market includes some large strategic participants, the central bank can achieve superior outcomes if intervention takes the form of a rule or "schedule," indicating commitments to buying and selling different quantities of foreign currency conditional on the exchange rate. Exchange rate management and reserve management can then be treated as two independent objectives by the central bank. This would enable a central bank to pursue exchange rate objectives with minimum reserve changes, or achieve reserve targets with minimum impact on the exchange rate. Broto (2013) analysed the effects of daily forex interventions in four Latin American countries with inflation targets (Chile, Colombia, Mexico and Peru) and found that first interventions, either isolated or initial, reduce exchange rate volatility, as a rule, although their size plays a minor role. Results support the signalling effect of central bank interventions under inflation targeting regimes. Humpage (2013) found that Switzerland's recent experience goes a long way to illustrate why the foreign-exchange intervention did not afford the Swiss National Bank with a means of systematically affecting the franc independent of Swiss monetary policy, and it left the Bank exposed to foreign-exchange losses. To affect exchange rates, central banks must change their monetary policies.

Suardi \& Chang (2012) found purchases and sales of US dollars intervention produces correlation asymmetry in the USA but not in Japan and Germany. Furthermore, the conditional correlation is stronger when central bank intervention frequency and amount increase. Menkhoff (2012) found that interventions in emerging markets are different from those in advanced economies. Central banks have considerable leverage, derived from relatively high reserves, some non-sterilization, the central bank's information advantage and capital controls. Consequently, these interventions often successfully impact the level and volatility of exchange rates. Goyal \& Arora (2012) found that variations in the euro/ dollar rate strongly affect the rupee/dollar level and volatility. The interest rate differential has strong perverse effects, tending to increase variance and depreciate exchange rate in India. News decreases volatility as it adds to scarce informa- 
tion. Domestic policy variables affect both level and volatility, and persist at the monthly frequency, but sometimes work at cross-purposes. Berganza \& Broto (2012) found that although inflation targeting leads to higher exchange rate instability than alternative monetary strategies, central bank interventions in some countries that adopted inflation targeting have been more effective to lower volatility than in countries that did not adopt inflation targeting.

Adler \& Tovar (2011) showed that central bank interventions slow the pace of appreciation exchange rate but the effects decrease rapidly with the degree of capital account openness. At the same time, interventions are more effective in the context of already overvalued exchange rates. Garcia, Restrepo and Roger (2011) point out that smoothing the exchange rate helps both financially-robust economies and financially-vulnerable emerging economies in handling risk premium shocks and, given a small weight placed on the exchange rate, the effects on inflation and output volatility are minimal with demand and cost-push shocks. Financially-vulnerable economies are especially likely to benefit from exchange rate smoothing due to perverse movements of the exchange rate they experience when hit by demand shocks and being more prone to risk premium shocks.

\section{Empirical data and results}

Developing countries and emerging countries that have adopted inflation targeting, in addition to interest rates, increasingly use central bank intervention as an auxiliary instrument to mitigate shocks in the foreign exchange market. Traditional models which central bank use as an auxiliary tool in the decision making of monetary policy generally do not include this channel. However, conventional models of strict inflation targeting do not deal with the variability of the exchange rate and the stability of financial markets. Since the intervention has been increasingly used by central banks to prevent the cycle of the exchange rate, it is necessary to include this channel in the model. This channel function so that, in case of sudden depreciation of the exchange rate, the central bank intervenes by selling foreign exchange reserves and thereby prevents the overflow of depreciation on domestic prices, or vice versa, in the case of appreciation, it intervenes by buying foreign currency and accumulating foreign exchange reserves.

Central bank interventions ( $F X$ int) in the model are defined by the equation:

$$
\mathrm{FX} \mathrm{int}_{t}=\omega^{1} \cdot\left(\mathrm{s}_{t}-\mathrm{s}_{t-1}\right)
$$


where $\left(\mathrm{s}_{t}-\mathrm{s}_{t-1}\right)$ represents the change in the exchange rate at which the central bank reacts, and parameter $\omega^{1}$ reflecting the preferences of the central bank to use foreign exchange intervention to prevent the cycle of exchange rates. If we want to model the behaviour of the central bank that does not use foreign exchange intervention, the value of this parameter should be set to zero, which excludes this channel.

The exchange rate in inflation targeting is determined on the basis of uncovered interest parity, whose equation looks like this:

$$
s_{t}=E s_{t+1}+\left(-i_{t}+i_{t}^{*}+\text { prem }_{t}\right)+\varepsilon_{t}^{s}
$$

For the easier understanding of this equation, let us rearrange it the way to put the expected change in the exchange rate $\left(E s_{t+1}-s_{t}\right)$ to the left, while the other differences in the returns on the two interest rates remain on the right side.

$$
E s_{t+1}-s_{t}=\left(i_{t}-\left(i_{t}^{*}+\text { prem }_{t}\right)\right)-\varepsilon_{t}^{s}
$$

Return on investment in a foreign exchange market is measured by the difference in yields of the two currencies. The starting point is the return obtained on a secure foreign currency $(i)$ as the minimum that is expected. Due to the lack of confidence of the participants in the foreign exchange market, they require extra yield that in the equation represents the risk premium of the country (prem). If a central bank offers higher yields $(i)$ than the local currency neutral $\left(i_{t}^{*}+\right.$ prem $\left._{t}\right)$, the domestic currency will become more attractive, which will lead to appreciation of the exchange rate $(s)$. As yields on two currencies tend to equalize, it means the expectation of exchange rate depreciation in the future $\left(E s_{t+1}\right)$. In other words, the uncovered interest parity implies that, due to rising interest rates, exchange rate appreciates but the expectation is that it will depreciate because after every appreciation of the exchange rate, depreciation follows and vice versa. The shock $\left(\varepsilon_{t}^{s}\right)$ in the equation represents a disturbance in the economy that is not included in the model and it affects the movement of the exchange rate.

The equation of uncovered interest parity in the model proposed here has been modified to include the effect of central bank interventions in the foreign exchange market:

$$
s_{t}=E s_{t+1}+\left(-i_{t}+i_{t}^{*}+\text { prem }_{t}\right)-\omega^{f x} \cdot F X \text { int }_{t}+\varepsilon_{t}^{s}
$$

The parameter $\left(\omega^{f x}\right)$ represents the estimated effect that central bank intervention had on the exchange rate cycle and it can depend on many factors such as liquid- 
ity of the financial system, central bank credibility, the political situation in the country, etc. If there is a depreciation shock $\left(\varepsilon_{t}^{s}\right)$ to any movement of the exchange rate, the central bank reacts with foreign exchange interventions (equation 1). In this way, the central bank increases the demand for domestic currency, which neutralizes the effect of the initial depreciation shock. If we assume that the central bank will intervene in the foreign exchange market, i.e. if the parameter $\omega^{1}$ in equation (1) is set to zero, the variable ( $F X$ int) will have no movement, so equation (4) reduces to equation (2).

\section{Results and discussion}

The following discussion is on displayed transmissions depreciation of the exchange rate shock in inflation targeting with and without the use of central bank interventions. As this is a linear model, this means that the reaction to the appreciation shock looked exactly the same, only with the opposite sign, i.e. instead of growth we would see a fall and vice versa.

To perform this exercise, MatLab software package with additional tools IRIS was used that contains a package of functions for solving the model and perform various calculations based on them. It creates a simulation of the period of 20 quarters (5 years) in which it is assumed that there is a one-time shock in the first period, and then it disappears.

If it comes to an exchange rate shock, which may be due to some instability in the foreign exchange market, it can lead to depreciation of the exchange rate. This depreciation would mean a rise in import prices, which could then spread to domestic prices. The central bank may react to the shock by increasing interest rates, which would neutralize the effects of depreciation shock. However, the higher interest rates would mean a restrictive monetary policy, which would then have negative consequences on the output gap. If the central bank estimates that the exchange rate shock is temporary, it may decide to stifle the foreign exchange market instability with foreign exchange interventions, which would then require a lower response interest rate.

Figure 1 shows the simulations of one-percentage ( $4 \%$ annualized) exchange rate shock and the responses by two central banks. The solid line represents a central bank that has adopted a strict inflation targeting, without foreign exchange intervention, while the dashed line represents the central bank that has made foreign exchange interventions to prevent sudden exchange rate cycle. 
Note that the central bank that has not intervened in the foreign exchange market recorded a higher depreciation of the exchange rate, and thus the higher price increase. Although the opening of depreciation gap had a positive effect on the output gap in this case, after some time, when the effects of depreciation gap have been absorbed, tight monetary policy will prevail, which is why the output in the coming period falls below the equilibrium state (negative output gap).

In the case of the other central bank, which uses foreign exchange reserves as an auxiliary instrument, we can observe small changes in the economy. The foreign exchange intervention has largely absorbed the depreciation shock and, therefore, we see lower inflation. As a result of lower price growth, the need for the reaction of monetary policy interest rate is also lower.

Figure 1: Exchange rate shock
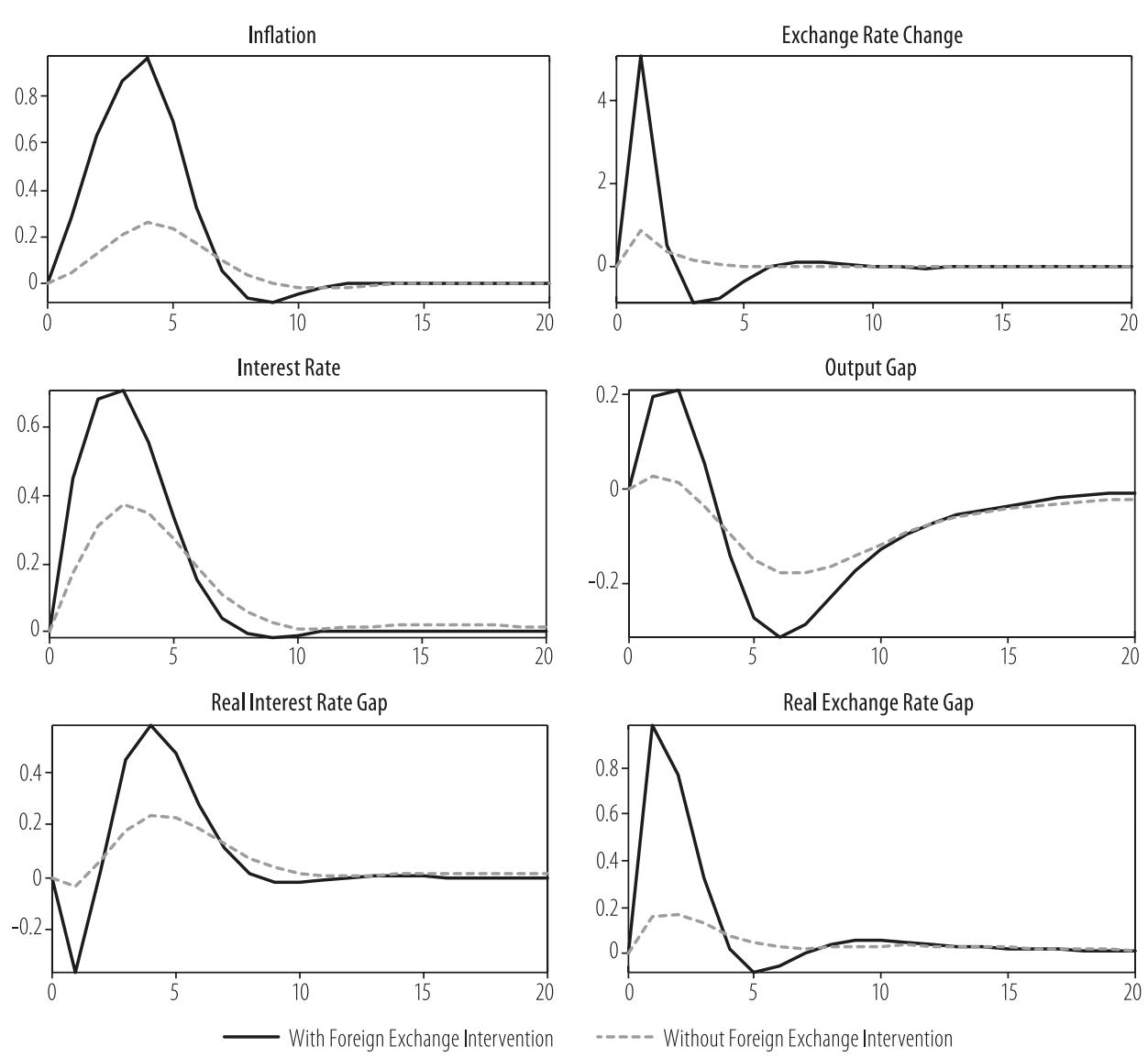

Source: Author's calculations 
Based on this example, we can see that central bank intervention can be very useful in some cases to redress the disorder in the foreign exchange market. Therefore, some central banks accumulate foreign exchange reserves at a very high level in order to have enough space for foreign exchange intervention, without the risk of foreign exchange reserves falling below the optimum level.

\section{Conclusion}

In a fixed exchange rate regime, the central bank intervenes in order to achieve and maintain the target exchange rate. In a flexible exchange rate regime, the role of the central bank is smaller. Even then the interventions are necessary, especially if the foreign exchange market becomes unstable due to excessive shortterm volatility, trends fuelled by trade rather than fundamentals or overshoot, and the underperformance of the exchange rate, and if the economy is exposed to the shock so that the exchange rate must adjust to a new equilibrium level and the central bank has to intervene in order to avoid the collapse of the foreign exchange market and facilitate the transition to a new equilibrium.

Developing and emerging countries that have adopted inflation targeting, in addition to interest rates, have increasingly used foreign intervention as an auxiliary instrument to mitigate shocks in the foreign exchange market because the exchange rate cycles jeopardize the achievement of inflation targets. In a situation where an extreme shock impacts the foreign exchange market to such an extent that seriously endangers liquidity and leads to dysfunction of the foreign exchange market, foreign exchange reserves would be an important weapon of monetary policy. Foreign exchange reserves allow the central bank to intervene in the foreign exchange market in order to maintain liquidity, support trade and limit the exchange rate cycle that occurs due to the dynamics based on the liquidity problems, rather than to change the equilibrium exchange rate associated with the initial shock. Also, foreign reserves enable the central bank to achieve the function of the lender of last resort, which means that in terms of widespread liquidity, the central bank injects liquid assets through loans and other instruments in order to accelerate the recovery of the banking system.

This paper presents the transmission depreciation of the exchange rate shock in inflation targeting with and without the use of central bank intervention. In case of an exchange rate shock, which may be due to some instability in the foreign exchange market, it can lead to depreciation of the exchange rate. This depreciation would mean a rise in import prices, which could then spread to domestic prices. The central bank may react to the shock by increasing interest rates, which 
would neutralize the effects of depreciation shock. However, the higher interest rate would mean a restrictive monetary policy, which would then have negative consequences on the output gap. If the central bank estimates that the exchange rate shock is temporary, it may decide to stifle the foreign exchange market instability with foreign exchange interventions, which would then require a lower response interest rate.

Econometric analysis showed that the central bank that has not intervened in the foreign exchange market recorded higher depreciation of the exchange rate, and thus a higher price increase. Although the opening of depreciation gap had a positive effect on the output gap in this case, after some time, when the effects of depreciation gap have been absorbed, tight monetary policy will prevail, which is why the output in the coming period falls below the equilibrium state (negative output gap). On the other hand, the central bank which that used currency reserves as an auxiliary instrument and intervened in the foreign exchange market has largely absorbed the depreciation shock and, therefore, we see lower inflation. As a result of lower price growth, the need for the reaction of monetary policy interest rate is also lower. Based on the examples presented in this paper, we can see that central bank intervention in some cases can be very useful in order to redress the disorder in the foreign exchange market. Therefore, some central banks accumulate foreign exchange reserves at a very high level in order to have enough space for foreign exchange intervention, without the risk of foreign exchange reserves falling below the optimum level.

Based on the above-conducted empirical research, significant implications for future research can be made. First, central bank intervention in inflation targeting is used to secure the necessary liquidity in the foreign exchange market, prevent the exchange rate cycle, prevent the currency crisis and, consequently, preclude the extreme fluctuation of the interest rate, all with the aim of achieving a defined inflation target or the inflation target range. Second, in the floating exchange rate regime, the central bank most often intervenes to counter the short-term trends in the exchange rate (the "leaning with the wind" hypothesis, the so-called pro-cyclical foreign exchange intervention). Also, foreign exchange interventions are used to correct the medium-term mismatch between the exchange rate (the "leaning against the wind" hypothesis and the so-called countercyclical foreign exchange intervention). Third, the role of a central bank intervention depends on the monetary strategy. When targeting the foreign exchange rate (fixed exchange rate), the central bank intervenes to achieve and maintain the target exchange rate. In the fixed exchange rate regime, a direct link (via the interest rate) is established between the balance of payments and the money supply. In other words, the change in the balance (imbalance) of the balance of payments is equal to the 
change in foreign exchange reserves. The exchange rate is constant and foreign exchange reserves are changing. The link between the balance of payments and the money supply can be partially interrupted by sterilization (depending on the level of foreign exchange reserves and capital mobility). In the event of a deficit in the balance of payments, the central bank should sell foreign exchange reserves and buy domestic government bonds. In the case of a surplus, it needs to buy foreign exchange reserves and sell domestic government bonds. Monetary policy is inefficient at a fixed exchange rate (with full capital mobility). On the other hand, in the inflation targeting (flexible exchange rate), if the exchange rate cycle threatens to achieve inflation targets, the central bank should intervene in the foreign exchange market in order to achieve a defined target inflation or a range of inflation targets. In this regime, a direct connection (via the foreign exchange rate) is established between the balance of payments and the money supply. In other words, the change in the balance (imbalance) of the balance of payments is equal to the change in the exchange rate. Foreign exchange reserves are constant and the exchange rate is changing. Fiscal policy is inefficient in a flexible exchange rate (with full mobility of capital). Fourth, for a small and open economy, the movement in the exchange rate that causes changes in the value of the trade weighted effective exchange rate (both nominal and real) has a significant impact on the economy, especially on inflation and GDP. In addition, a foreign exchange rate can be broken. In this case, central bank intervention can limit the rate of exchange rate deviation thus avoiding such a negative impact and the need for costly real macroeconomic adjustment. In the flexible exchange rate regime, there is no target exchange rate and interventions are aimed at correcting and preventing excessive and persistent volatility of the exchange rate, but not against the exchange rate changes that are in line with the fundamentals. If the pressure on the exchange rate reflects the fundamental economic forces, then it is not necessary to intervene but to adjust the exchange rate. The optimal degree of exchange rate flexibility depends on a number of country-specific features, including: openness of the economy, rigidity of prices and earnings, the level of short-term and medium-term exchange rate transfers, the possibility of substituting domestic and imported goods, the state of the banking system, and the volume and nature of the financial dollarization. Fifth, in inflation targeting, central bank intervention in the foreign exchange market should not jeopardize the achievement of price stability or the inflation target. Also, achieving low inflation in the medium-term horizon should be achieved by avoiding unnecessary instability in the yield, interest rate and exchange rate. In other words, the central bank must make sure that any inflationary or deflationary impacts due to interventions do not generate inflation out of the target. Finally, central bank intervention in the inflation targeting should be compatible with the short-term goals of macroeconomic policy. In other words, the macroeconomic policy of central bank intervention should 
keep achieving full employment and low inflation (internal equilibrium) and current account sustainability (external equilibrium). Further empirical research is needed to point out positive consequences of central bank interventions and their importance in the absorption of internal and external shocks, the prevention of cyclical movements in the foreign exchange market, the prevention of exchange rate cycles, and the positive impact on nominal and real macroeconomic variables, which are significantly analysed in this paper. Empirical results in this paper can be used as suggestions and recommendations for the implementation of macroeconomic (monetary) policy. 


\section{References}

1. Abbuy, K.E., 2018. An Empirical Test for the Effectiveness of Central Bank Interventions in Foreign Exchange Markets: An Application to the Canadian and Swiss Central Banks. MPRA.

2. Adler, G. and Tovar, C. E., 2011. Foreign Exchange Intervention: A Shield Against Appreciation Winds? IMF Working Paper WP/11/165.

3. Adler, G. and Tovar, C. E., 2014. Foreign exchange interventions and their impact on exchange rate levels. Monetaria, Centro de Estudios Monetarios Latinoamericanos.

4. Atish, R.G., Ostry, J.D. and Chamon, M., 2014. Two Targets, Two Instruments: Monetary and Exchange Rate Policies in Emerging Market Economies. International Monetary Fund.

5. Basu, K. and Varoudakis, A., 2013. How to move the exchange rate if you must: the diverse practice of foreign exchange intervention by central banks and a proposal for doing it better. World Bank Policy Research Working Paper 6460.

6. Berganza J.C. and Broto, C., 2012. Flexible inflation targets, forex interventions and exchange rate volatility in emerging countries. Journal of International Money \& Finance.

7. Blanchard, O., G. Adler and de Carvalho Filho, I., 2015. Can Foreign Exchange Intervention Stem Exchange Rate Pressures from Global Capital Flow Shocks? NBER Working Paper 21427.

8. Broto, C., 2013. The effectiveness of forex interventions in four Latin American countries. Emerging Markets Review.

9. Canzoneri, M. and Cumby, R., 2013. Optimal Foreign Exchange Intervention in an Inflation Targeting Regime: some cautionary tales.

10. Cavallino, P., 2017. Capital Flows and Foreign Exchange Intervention. International Monetary Fund, mimeo.

11. Chang, R., 2017. Foreign Exchange Intervention Redux. Rutgers University and NBER.

12. Cheng, A., Das, K. and Shimatani, T., 2013. Central bank intervention and exchange rate volatility: Evidence from Japan using realized volatility. Journal of Asian Economics.

13. Choi, E.K. and Jin, H., 2014. Currency intervention and consumer welfare in an open economy. International Review of Economic \& Finance.

14. Cun, W. and Li, J., 2016. Sterilized Intervention and Optimal Chinese Monetary Policy. 
15. Daude, C., Levy Yeyati, E. and Nagengast, A., 2014. On the effectiveness of exchange rate intervention in emerging markets. OECD Development Centre Working Paper 324.

16. Dutt, D. 2018. The Costs of Foreign Exchange Intervention. Allied Social Science Association Conference 2018 Philadelphia, United States.

17. Fabris, N. 2018. Challenges for Modern Monetary Policy. Journal of Central Banking Theory and Practice,7(2), pp. 5-24.

18. Fabris, N. 2019. Cashless Society - The Future of Money or a Utopia?", Journal of Central Banking Theory and Practice, 8 (1), pp. 53-66.

19. Fanelli, S. and Straub, L., 2017. A Theory of Foreign Exchange Interventions. MIT.

20. Fatum, R. 2015. Foreign exchange intervention when interest rates are zero: Does the portfolio balance channel matter after all? Journal of International Money and Finance, Vol. 57, Issue C.

21. Fatum, R. \& Yamamoto, Y., 2014. Large versus Small FX Interventions. Journal of Banking and Finance, Vol. 43

22. Fatum R., Pedersen J. and Sorensen, P.N., 2013. The intraday effects of central bank intervention on exchange rate spreads. Journal of International Money and Finance.

23. Fernandes, G., 2013. Interventions in the Brazilian Foreign Exchange Market: An Empirical Investigation of the Determinants. Itaú. Working Paper No. 9.

24. Fratzscher, M., Gloede, O., Menkhoff, L. Sarno, L. and Stöhr, T., 2017. When is foreign exchange intervention effective? Evidence from 33 countries. German Institute for Economic Research, DIW Berlin, Discussion Papers 1518.

25. Fry-McKibbin, R.A. and Wanaguru., S., 2013. Currency intervention: A case study of an emerging market. Journal of International Money and Finance.

26. Garcia, C. J, Restrepo, J.E. and Roger, S., 2011. How much should inflation targeters care about the exchange rate? Journal of International Money and Finance 30(7), 1590-1617.

27. Goyal A. and Arora, S., 2012. The Indian exchange rate and central bank action: An EGARCH analysis. Journal of Asian Economics.

28. Guler, A. 2020. Does Monetary Policy Credibility Help in Anchoring Inflation Expectations? Evidence from Six Inflation Targeting Emerging Economies. Journal of Central Banking Theory and Practice, 10 (1), pp. 93 112.

29. Humpage, O. F., 2013. The Limitations of Foreign-Exchange Intervention: Lessons from Switzerland. Federal Reserve Bank of Cleveland.

30. Jin, H. and Choi, E.K., 2013. Profits and losses from currency intervention. International Review of Economic \& Finance. 
31. Katusiime, L. and Agbola, F. W., 2018. Modelling the impact of central bank intervention on exchange rate volatility under inflation targeting. Applied Economics.

32. Krušković, B., 2014. Monetary Strategies, Exchange Rate and Foreign Exchange Reserves. Economics Faculty, University of Banja Luka.

33. Menkhoff, L., 2012. Foreign Exchange Intervention in Emerging Markets: A Survey of Empirical Studies. Leibniz Universität Hannover Discussion Paper No.498.

34. Montoro, C. and Ortiz, M., 2016. Foreign exchange intervention and monetary policy design: a market microstructure analysis. Central Reserve Bank of Peru, Working Paper Series.

35. Mundaca, G., 2018. Central bank interventions in a dollarized economy: managed floating versus inflation targeting. Empirical Economics.

36. Suardi, S. and Chang, Y., 2012. Are changes in foreign exchange reserves a good proxy for official intervention? Journal of Finance Markets, Institutions and Money.

37. Trivedi, S.R. and Srinivasan, B., 2016. Impact of Central Bank Intervention in the Foreign Exchange Market: Evidence from India Using an Event Study Approach. The Economic Society of Australia, Economic Papers Vol. 35 Issue 4.

38. Williams, J. C., 2014. Inflation Targeting and the Global Financial Crisis: Successes and Challenges. Federal Reserve Bank of San Francisco. 